\title{
Ashtar's Forum Theatre: Writing History in Palestine
}

\section{Rania Jawad}

Representations of Palestinians in U.S. mainstream media have been heavily marked by violence, the image of which is often an impassioned, militant terrorist or a misguided enemy. ${ }^{1}$ These representations, which govern a very specific discourse about Palestinians, have over the years become a dominant form of documentation of the Palestinian people. The accumulation and reiteration of these representations thus serve as a kind of history, one that highlights very specific images while ignoring and occluding others. By understanding history in this way, as a selective narrative construction of images and texts, I will look at the theatre as another medium in the production of history, specifically as an alternative to such dominant narratives produced and circulated by mainstream mass media.

In this article, I focus on the work of one Palestinian theatre's use of a specific type of performance as a form of what I call history-writing. I am drawing on the work of the Popular Memory Group in my use of this phrase, which I will elaborate on later in the article. ${ }^{2}$ My use of the term writing is an expansive one, along the same lines as the understanding of what constitutes a text. I therefore understand writing to include acts beyond literal transcription. By using the phrase historywriting in my discussion of Palestinian theatre and performance, I aim to emphasize the dialogue and permeability between text and embodied practice in general, and specifically within the theatre, thus pushing against a neat separation between the two. I will examine the Ashtar School for Theatre Production and Training, which established itself in Jerusalem as a nonprofit NGO in 1991, because of its use of a community-oriented Forum Theatre. I choose to focus on Ashtar's use of Forum Theatre, based on the work of the Brazilian theatre practitioner Augusto Boal, as it enacts a particular form of history-writing that is as much about the present and future as it is about the past.

My intention is not to offer an analysis of dominating narratives, whether produced outside or within Palestine, that inscribe Palestinians or to trace the process of how they have been represented and how these representations have changed over the years. Rather, I want to begin to highlight a practice of history-writing based on self representation and social interaction, specifically within the context

\footnotetext{
Rania Jawad is a Ph.D. student in the Department of Middle Eastern and Islamic Studies at New York University. Her research focuses on Palestinian theatre, for which she has been awarded a Fulbright-Hays Fellowship and an NYU Torch Fellowship to conduct research in Israel/Palestine for the 2008-2009 academic year. She completed her Master's in the German Department at NYU writing on popular education and the early theatre work of Bertolt Brecht.
} 
of Palestinians living inside the West Bank. ${ }^{3}$ After situating the frame of looking at theatre performance as a form of history-writing, I will briefly examine how oral narrative forms in Palestinian culture have been used in its theatre. In doing so, I want to foreground certain elements that will illuminate the mediating role of what is called the "Joker" in Forum Theatre. In my discussion on Ashtar's use of Forum Theatre, I hope to reveal a form of history-writing that seeks to engage us as both product and producer of history, capable of enacting social and political change.

\section{Representation, Theatre Performance, and History-writing}

While representations of Palestinians in the U.S. mainstream media may not directly affect the theatre being made in Palestine, they are in the backdrop when analyzing Palestinian theatre and performance. In reproducing dominant representations, mass media mark, to a certain degree, our lens of analysis, especially when analyzing mediums such as theatre and performance, which are themselves constituted by the very acts of representation. If, as according to Stuart Hall, representation is central to "the processes by which meaning is produced," then how events and experiences are understood is largely due to how they are represented. ${ }^{4}$ Thus, analyzing how events and experiences get framed in order to produce particular meanings is very revealing. For example, the representation of Palestinians in U.S. mainstream media is not merely a representation but a very powerful ideologically constituted discourse about the Palestinians. ${ }^{5}$ In other words, how Palestinians are represented says more about those representing than those being represented. Although an understanding of how particular systems of meaning become institutionalized, privileged, and abused will not remedy the position of the marginalized, it can work toward undermining authoritative discourses.

Edward Said describes After the Last Sky, a book composed largely of photographs and text, as an attempt to engage with the difficulty of writing about and representing Palestinians. "It is a terribly crowded place" in terms of representation, he writes, remarking elsewhere how the construction of Palestine and Palestinians has been and continues to be "conducted both on the ground in Palestine and outside Palestine, as an ideological, informational, and interpretative conflict." ${ }^{\prime 6}$ Mass media, of course, are not the only player, but are joined by think tanks, travelogues, and academic scholarship, among others. One can therefore argue that Palestine itself has been dominated by the very discourse on Palestine. For not only has the proliferation of writing about Palestine worked to silence Palestinians themselves, but, as Said notes, their historical presence on the land was not in itself enough for them to be written into history. ${ }^{7}$ The establishment of the state of Israel on the land of Palestine in 1948 marked the end of not only a homeland for Palestinians, but a way of life - in short, a historical existence that did not have to prove that it existed. In other words, their physical presence was not equal to the historical narrative. It is along these lines that history must be read as a narrative 
that is written, a site of construction as much as contestation.

Against this background, I want to situate theatre performance as an alternative medium of producing and writing history-one that is also a social event and collective practice and that, while attuned to a number of different audiences, directly engages a local Palestinian population. ${ }^{8}$ By using the term performance, I am focusing on the acts of the theatre, in other words, the processes of making theatre and the social dynamics during the performance itself, as opposed to the textual analysis of script and content. The frame of the theatre is particularly apt within the Palestinian context regarding history-writing and the politics of representation, not only because the word representation has both aesthetic and political connotations, but also because Palestinians have often been denied self representation, along with self determination, for over sixty years. ${ }^{9}$

While what plays out on the theatrical stage is not necessarily a direct reflection of society, it is nonetheless firmly grounded in historical and sociopolitical contexts and offers another frame in which experience is represented. Performances are therefore not only products of their particular contexts but also active interventions in them. Performance as presenting (and representing) knowledge and experience, whether social, cultural, political, or personal, is an act of transmitting and circulating knowledge an act-I suggest, of history-writing. ${ }^{10}$ In drawing on the Popular Memory Group, history is thus defined by its "past-present relationship." 11 For if history is considered as something that is written - in other words, as created by persons who themselves are in history, who are at the same time a product of their history as they are writing another, whether directly their own or that of others - then the historical record is also a record of the present.

For Palestinians, whose past has been denied and who must struggle "with and against a still much contested present," the writing of their historical record is very much also about their future. ${ }^{12}$ Barbara Harlow describes the literary and critical writing of Palestinian Ghassan Kanafani in this way, situating history among its relationship to the present and future, as well as the past. ${ }^{13}$ She notes how his works "participate in the making of Palestinian history, as theory and practice, both as archival record and document and as active forms of continued political resistance." His "reconstructions of the past," she continues, "contribut[ed] to the making of the vision of the future that it would sponsor." 14 In other words, Kanafani's practice of writing Palestinian history via his literature was as much about the past as it was about the future. Furthermore, according to Harlow, his practice was as much about configuring what kind of future was not only possible but desired.

Within this frame I want to analyze Palestinian performance, specifically Ashtar's Forum Theatre, as a form of history-writing. Understanding the construction of history beyond the documentation of past events, as well as beyond the privileged spaces of academic institutions, allows for a view of history as part of a larger process of social production. By expanding the frame, history can then be 
understood as a collective production in which all participate, albeit unequally. ${ }^{15}$ The theatre can be understood as a stage where Palestinians are representing themselves to local audiences and in the wider public sphere, thus contributing to the production and circulation of knowledge about Palestine and Palestinians.

\section{Oral Narrative Forms in Palestinian Culture and Theatre}

With regards to the above contextualization, I want to highlight briefly certain ways that oral narrative forms in Palestinian culture have been used in its theatre, which will illuminate why the Joker is instrumental in the practice of Ashtar's Forum Theatre. Oral historian Rosemary Sayigh suggests that oral narratives are integral to the writing of Palestinian history for at least two significant reasons. First, the devastation of 1948, in which more than half of the Palestinian population was dispossessed, over four hundred villages destroyed, and the land either militarily occupied or placed under foreign jurisdiction, is a legacy that continues into the present. ${ }^{16}$ The destruction (and continual confiscation) of Palestinian archives, in addition to the absence of a nation-state to support official institutional mechanisms to establish and preserve a Palestinian historical record, are but two examples of this legacy. ${ }^{17}$ Second, what she calls "the Euro-American mode of history writing" and the writing of a national history both tend to marginalize certain groups' experiences, such as those of women, rural populations, and the uneducated. ${ }^{18}$ Moreover, oral culture in Palestinian and Arab societies has a long and very rich history, which in part accounts for the importance given to poetry readings, folk songs, and the practice of storytelling.

In the realm of Palestinian theatre, oral narratives have been used in both content and form. Samia Qazmouz al-Bakri's one-woman performance al-Zarub (The Alley) is one example. In her article, "Stories from under Occupation: Performing the Palestinian Experience," Hala Nassar examines the play as a performance of collective memory. The play consists of a female storyteller who speaks about life in Palestine before 1948, interwoven with al-Bakri's own life in present day Acre. She tells stories of Acre's al-Ahl Cinema, which was torn down and replaced by a branch of the Israeli National Bank. She describes Acre's Pasha Baths, which were turned into an Israeli museum; parts of the seashore, which are now Israeli private property; and Khan al-Umdan, the famous lane at the center of Acre where Palestinian children used to gather in front of Sanduk al-'Ajab [The Box of Wonders], which is now closed, the "keys ... with an Israeli company for urban development." 19 Through her narration, al-Bakri cites specific examples to illuminate the ongoing process of eliminating tangible markers of Palestinian life by replacing them with Israeli ones. The dual process of erasing Palestinian history and establishing Israeli "facts on the ground" is not only part of an extended history of colonial-national politics, but also a tool of writing an Israeli history. ${ }^{20}$

Al-Bakri's performance works against this rewriting of history not merely 
by recalling Palestine pre-1948, but by creating a social space in which to reenact specific recollections. This begins even before her entrance, for her stage directions call for the performance space to be lined with photographs and paintings of Acre pre-1948. ${ }^{21}$ During the performance, al-Bakri interacts with the images, pointing to places and scenes as part of her narration. Based on interviews with Palestinian women villagers who lived through 1948 and now reside in Israel, the content of al-Bakri's play is comprised of the very words of these oral narratives. ${ }^{22}$ She tells their stories, thus documenting and putting into circulation Palestinian oral histories. Nassar also notes that the manner in which al-Bakri tells these stories directly draws on the traditional figure of the storyteller in Palestinian culture. ${ }^{23}$ Thus, drawing on both the content of oral narratives and the form of storytelling, her performance is an act in the present that engages with how the past is understood, reconstructed, and re-presented.

In Palestinian theatre productions, the traditional figure of the storyteller ( $\mathrm{al}$ hakawati in Arabic) has reappeared at different times and in various contexts. ${ }^{24}$ While al-hakawati is often used as an attempt to invest contemporary theatre productions with a degree of authenticity and legitimacy, countering the claim that theatre in the Arab world is purely a Western import, ${ }^{25}$ it also emerges because of its "communicative strategies" with the audience. For example, alternating between the past and present and directly addressing the audience are tools of al-hakawati. Al-hakawati acts as both narrator and commentator of past and present events as a means to engage with the audience, as well as imbue the narration with particular meanings. In her discussion on the strategies of al-hakawati, Friederike Pannewick describes the ability of al-hakawati "to use the transmitted text connotatively, in order to declare his position concerning current events taking place within his society." ${ }^{26}$ Along with other early, popular theatrical forms, such as jesters, mimes, and mimics, the tradition of al-hakawati is often filled with sharp political and social critiques. ${ }^{27}$ Thus, the act of narration often served as a technique to frame familiar material in order to communicate a particular political purpose to a local audience. $^{28}$

One, and perhaps the most well known, example of how the figure of the storyteller has been at times utilized in Palestinian theatre productions is the Palestinian theatre troupe al-Hakawati. Taking its name from the traditional figure of the storyteller, al-Hakawati was founded in 1977 by Palestinian citizens of Israel and residents of East Jerusalem and the West Bank. ${ }^{29}$ While they did not incorporate the figure of al-hakawati directly into all their plays, their process of producing theatre specifically echoes some characteristics of the traditional hakawati as an itinerant storyteller that performs in public places. Troupe member (and later cofounder of Ashtar Theatre) Edward Muallem describes al-Hakawati's strategy of performing as follows: 
We would go to a village and would stay there for two days, build a stage in the center of town, live with the people for two days and put on a performance. This was the particular experience of al-Hakawati, developing a relationship with the audience before the performance. ${ }^{30}$

Because of the lack of theatre and community spaces to host performances, alHakawati decided to build the stage themselves, fully equipped with sounds and lights. By traveling from village to village, they followed the steps of the itinerant storyteller, transforming the one-man performance of the traditional hakawati into a large production, with lights, a sound system, and very elaborate visual props and costumes. Adapting and expanding the form of the traditional storyteller thus served in developing al-Hakawati's relationship with their audience.

Through performances in cafes, public squares, and schoolyards, al-Hakawati juxtaposed the theatre of art and the stage of everyday life, at times revealing them as one. Radi Shehadeh, a member of al-Hakawati, recalls making the rounds in a suburb of Jerusalem in a car with a loudspeaker mounted on top. Requesting the people's attendance at a performance in the main square, the "amplified announcement mimicked the orders of the Israeli military government," whose public pronouncements usually signified curfews, arrests, and imprisonments: "O people of al-Mukabber, by order of the Theatrical Governor, it is absolutely forbidden to remain at home ... and otherwise not be there in the town square.... El-Hakawati will be there, awaiting you. ${ }^{{ }^{31}}$ In the same way that the traditional hakawati reconfigured familiar narratives in order to communicate new meanings, al-Hakawati troupe appropriated the familiar language of the colonizer for their own purposes. In framing their narrative within what is forbidden, the troupe emphasized the necessity of forging another narrative, strengthened by its dependency on the collective. The act of attending a performance, in other words, represented active participation in the realization and circulation of that narrative. Moreover, this juxtaposition of art and social life was also used to enable a process of critiquing the politics within Palestinian society itself. In one performance, al-Hakawati member Muhammad Mahamid recalled how

attempts were made to activate the audience by inciting it against the character of the conservative reactionary in the play. The actors would descend into the audience and bring members back up onto the stage in order to silence this character, who would not cease spouting the need for traditional, conservative order. ${ }^{32}$

Al-Hakawati's process of producing theatre was very much a product of its particular political and social context. The fact that the troupe was working under Israeli 
military occupation "led to the development of a language full of subtle symbols, metaphors, as much as an artistic code between the theatre and its audience." ${ }^{\prime 3}$ For instance, political censorship and other forms of control were influential in the troupe's development of a collaborative process of making theatre. Plays were created through a process of collective improvisation around agreed upon subjects, not prewritten texts. Dov Shinar notes that the troupe claimed that plays were written solely for the benefit of the censorship authorities, "who nevertheless fail[ed] from time to time, to grasp the real meaning of the messages." ${ }^{34}$ Familiar tropes were used to both engage and activate audience members. ${ }^{35}$ As with the traditional hakawati, narratives took on various political meanings from the ways in which they were communicated.

Oral narrative forms, such as personal stories and the more traditional figure of al-hakawati, have been used in Palestinian theatre performances to serve a number of different purposes. Utilized in both content and form, oral narratives have contributed to making marginalized voices and experiences heard, as well as to developing a social space in which to comment upon and potentially offer political and social critiques. What is emphasized is the relationship between the performance and the audience, thus highlighting theatre performance as both a communicative act and a public event actively engaging its audience. Foregrounding these specific elements will help illuminate the practice of Ashtar's Forum Theatre as mediated by the role of the Joker.

\section{Ashtar's Forum Theatre}

Ashtar Theatre established itself in Jerusalem as a non-profit NGO in 1991 and later moved to Ramallah due to the closures and difficulties for West Bank Palestinians in reaching Jerusalem. Founded by two former members of al-Hakawati theatre troupe, Iman Aoun and Edward Muallem, Ashtar has developed a Theatre (and Drama) in Education (T/DIE) project, emphasizing theatre as a pedagogical and artistic tool, and the production of three types of theatre: a school theatre, a professional theatre produced in cooperation with local, Arab, and international participants, and a community oriented Forum Theatre, based on the work of the Brazilian theatre practitioner Augusto Boal. ${ }^{36}$ Although there have been a few workshops and other theatre practitioners who have used Theatre of the Oppressed techniques in Palestine, Ashtar defines itself as the center for Forum Theatre training in the West Bank. To this end, Ashtar organized the first Theatre of the Oppressed Festival in Palestine, held between April and June 2007, in which international theatre groups participated, including CTO-RIO, Boal's troupe from Brazil. ${ }^{37}$

A description of Forum Theatre found in Boal's early work, Theatre of the Oppressed, puts forth his definition of a theatre that transforms the spectators of a theatrical action into its protagonist, thus into transformers of a dramatic action, and by extension, their own society. ${ }^{38}$ In effect, audience members are encouraged to 
take the stage and offer alternative actions to the presented scenario. The emphasis on the spectator, or "spectactor" in Boal's terminology, thus widens its definition from the observer of a theatrical presentation to the individual as a member of and participant in society. Elaborating on this shift will elucidate the roles of spectatorship and history-writing within Ashtar's Forum Theatre. Understanding the context of producing and performing the Forum Theatre will reveal a practice of history-writing based on self-representation and social interaction, as discussed above. The function of history-writing thus shifts from the documentation of past events and circulation of knowledge toward the narration of future alternatives to the status quo.

The inception of Forum Theatre as one of Ashtar's ongoing programs is part of a larger social process that extends beyond the realm of cultural practice, one that focuses on internal Palestinian social politics. As in other struggles for national self-determination, concentration on the dominant political context often subsumes other issues of concern, such as class and women's rights struggles. The focus, therefore, lies not only on social issues of the Palestinian community but also their relation to wider national and transnational issues. Aoun situates Ashtar's work as a whole within the realm of community cultural work, where culture has been able to shape the sociopolitical awareness of the Palestinian community at large, in its numerous contexts. Forum Theatre fits into this project because it does not focus only on the production and presentation of a piece of theatre, but also in engaging the audience in an active participation to change the sociopolitical dynamics of its community. Aoun contextualizes the development of Ashtar's Forum Theatre within this effort:

In Palestine even the baby in its mother's womb is politicized, this is our destiny. So as we say here, we breathe politics and eat politics with our daily bread—but wait a minute, social politics aren't the same. Our society has many taboos and prohibitions especially when it comes to women's issues. ${ }^{39}$

By politicizing social issues, inextricably intertwined with the Palestinian struggle against Israeli state oppression, Aoun highlights how Palestinian society has also constructed its own oppressive structures. Along these lines, Ashtar uses Forum Theatre to broach taboo subjects in public spaces. Presenting narratives that are socially constructed by Palestinians is an attempt at self-critique. Ashtar ultimately aims to provoke change within their own society by first asking the audience to offer alternative narratives, in effect, a practice of Palestinians writing their own history.

Since 1997, Ashtar has produced and performed an annual Forum Theatre series, "Abu Shaker's Affairs," directed at a Palestinian public, performed in 
schools, villages, cities, and refugee camps. Echoing the strategy of al-Hakawati troupe, Ashtar travels to reach its audiences, reversing the theatrical convention that audience members travel to the theatre. This, of course, is not a mere subversion of a familiar pattern or an imitation of the traditional hakawati as itinerant storyteller. Because of the hundreds of Israeli military checkpoints scattered throughout the West Bank, heavy restrictions on the local Palestinian population make daily travel extremely cumbersome and difficult. Ashtar, registered as an NGO that receives support from international organizations, has an easier time navigating its travel. This is not to say that they have not faced obstacles in either their ability to travel inside and outside the West Bank or during the process of producing their performances. $^{40}$

Each year the Abu Shaker performance focuses on a different community and a specific issue within that community. The "Popular Theatre in Palestine Project," a civil society initiative proposed by Ashtar along with CARE International in the West Bank and Gaza, describes a noticeable lack in civil society organizations in Palestine to represent effectively all sectors of society. ${ }^{41}$ Therefore, Ashtar has chosen specific target audiences for its Forum Theatre: women, youth, the disabled, the unemployed, and other disadvantaged groups. As one example, the following is the scenario performed in "Abu Shaker's Affairs" in 1999:

\begin{abstract}
Masha'el is a young woman who was subjected to rape at eight years of age by her paternal uncle Abu Shaker. He forced her mother [in]to silence in return for support of the family following his brother's death. He even forced his under-age nephew to work as a car mechanic at his garage rather than allow him [to] go to school in order to safeguard the secrecy of the incident. At the moment [the rape] becomes known, Abu Shaker decides that the best means to deal with it is to have her brother kill Masha'el to redeem his and the family's honor. ${ }^{42}$
\end{abstract}

In this one scenario, Ashtar addresses such controversial subjects as child rape and honor killings, in addition to the attendant issues of patriarchy, child labor, and women's rights in general. By broaching such taboo subjects, Ashtar challenges Palestinian society to confront critical social problems, not to ignore them by focusing solely on the ongoing national struggle. While such factors as Israeli state oppression and U.S. imperialistic and militaristic practices in the region often serve to strengthen a conservative hold on certain practices and identities, Palestinians are not passive spectators in either the national arena or local spheres. Ashtar's Forum Theatre makes clear that Palestinians have agency both in perpetuating such social problems as well as confronting and attempting to end them.

The development of each "Abu Shaker's Affairs" script begins with a study and 
field discussion around an existing social problem. After engaging in discussions with community workers, as well as interviewing people to obtain case studies, Ashtar develops the skeleton of a production through a number of exercises. These include Image Theatre techniques (another methodology articulated by Boal), improvisations, and the training of "Jokers," among others. The Joker is a technique that incorporates active commentary on a play as part of the performance itself. After introducing the "rules" of the forum, the Joker facilitates a process whereby audience members interrupt the mechanisms and frames of the performance by stopping the action, stepping on stage and taking the place of the protagonist. The scenario is re-played and the spectactor must act out a solution to the problem, "providing alternate behaviors, choices, actions and wordings." 43 The Joker, therefore, mediates between the action of the play and the spectactors, motivating the audience not only toward analysis but toward physical action.

While not serving the same function, the Joker resembles the figure of alhakawati as a mediating figure between the audience and the presented narrative. In her discussion on the use of al-hakawati in Palestinian theatre, Nassar quotes Frantz Fanon's discussion on the role of storytelling as a political tool under colonization. Fanon describes how al-hakawati's familiar formula "this all happened long ago" was replaced by "what we are going to speak of happened somewhere else, but it might well have happened here today, and it might happen tomorrow." ${ }^{\prime 4}$ Taking the lead from this hakawati, the Joker strives to engage audience members as producers of future narratives. If al-hakawati has the ability to manipulate what is familiar in order to communicate alternative meanings, the Joker specifically provokes the audience to offer alternatives to the enacted scenarios. The physicality involved in the process of writing alternative scenarios on stage embodies the practice of history-writing itself.

In discussing the Joker in Ashtar's Forum Theatre, Aoun cites the Palestinian caricaturist Naji al-'Ali's most popular character, Handala, as a model. ${ }^{45}$ Handala is most often depicted as a ten-year-old boy in ragged clothes, barefoot, hands clasped with his back to the viewer. Positioned between the viewer and the scene, Handala exemplifies the child witness to his people's suffering and exile, as well as the corruption of Arab regimes and economic elites. Aoun quotes how al-'Ali defined Handala:

At the beginning, I introduced him as a Palestinian child. However with the development of consciousness, he acquired a national integrity and a universal human horizon. He is the witness of this undying age, who entered life forcefully and will never leave it. He is the legendary witness. ${ }^{46}$

Handala is witness to the many spectacles that inscribe Palestinian life and history. 
He becomes the lens of a frame that documents the realities of Palestinian life and death, narrating a history that has been actively erased and silenced. Although seldom directly involved in the events before him, he is part of the dynamic from passive to active witness. Publishing in Arabic newspaper dailies, al-'Ali describes his cartoon commentaries as a way not only to document but to "agitate people using simple language. ${ }^{\$ 77}$ In the medium of Forum Theatre, however, the function of the Joker is embodied by an immediacy that brings the audience directly onto a physical stage to rewrite the history that is being presented.

Drawing on al-'Ali's scrutiny of social and political taboos, Ashtar brings to the fore social problems that are often marginalized, such as the lack of women's rights, child labor, trading with rotten food, drugs, and violence in schools. The role of the oppressor as embodied in the character of Abu Shaker takes on a variety of roles, such as the autocratic father, collaborator with the Israeli occupation forces, or aggressive teacher. In 2001, “Abu Shaker's Affairs” focused on problems directly arising from Israeli retaliation and collective punishment for any form of Palestinian resistance. Specifically, the scenario addressed the poverty caused by Israel's continuous closure of the Palestinian territories, which caused a rise in child labor and the risk of increasing numbers of collaborators. The production, aimed at students thirteen years and older, is described as follows:

Shaker, the protagonist, is 13 years old, the oldest son of a family of six kids. His father lost his job as a construction worker in Israel due to the recent Intifada and is unable to find an alternative job. His mother is a passive woman who cares for him but does nothing to protect him. Shaker had to quit school in order to sell chewing gum to feed his family. His only friend, Anwar, whose father is a national activist, is a spoiled child who refuses to lend him money, boasting instead of having to move residence for security reasons, because his father is wanted by the Israelis. In great need of money, Shaker, convinced by two gang members, steals a radio from a car. He is caught red-handed, as he did not know that this was a setup. At prison the Israeli investigator treats him gently, showing him sympathy, and succeeds in turning him into a collaborator. The deal is that he should provide information about wanted persons in his neighborhood in exchange for payment. The first piece of information Shaker gives is the new address of Anwar's family, receiving a large sum of money in return. A few days later, a rocket hits Anwar's house, not killing his father but Anwar himself. Shaker is confused, in pain, and sorry for his action. ${ }^{48}$ 
The intricate dynamics of growing up in the West Bank are quite visibly and fluidly revealed in the above scenario: the impotence imposed on the male Palestinian population wherein a thirteen-year-old child must sell gum to feed his family; the mother figure unable to protect her young child; the arrogance of a young boy consumed by nationalist heroism, to name just a few of the issues often subsumed within less nuanced, hegemonic narratives. The staging of such a scenario gives voice to matters that may otherwise be suppressed by a socially imposed silence, while the narrative itself gives insight into the effects of Israeli state oppression on Palestinian social politics. ${ }^{49}$

In constructing the framework for each scenario, Ashtar feels

[it is] vital that each character have a clearly defined will. That will, like a personality, could not change Abu Shaker, as the oppressor, could not magically transform him.... [T] he audience/ players had to try to change the situation, through the dynamics, and the interaction, between the people on stage. Only in this way could it be used as a meaningful and relevant exercise.

In the forum, each actor stands in for a particular vision of the world, and it is up to the protagonist to change the situation by offering an alternative vision. What is emphasized are the social dynamics between those who are in varying ways party to the oppression, whether the oppressed, witnesses to the oppression, or other oppressors. The forum is meant to reveal society's behavioral attitudes and foster a "critical collective analysis of shared problems." ${ }^{50}$ The process of collecting data and personal experiences in order to produce the enacted scenario in the forum contributes to the multiple levels of history-writing that take place in the practice of Forum Theatre. This process of collection is also extremely important because of the lack of effectively functioning institutional apparatuses in the West Bank to conduct such work. As revealed in the performance of oral narratives discussed above, the creation of a public space in which to present, analyze, and actively engage with pressing issues can mobilize communities. Contributing to Ashtar's belief in theatre's role in developing civil society, ${ }^{51}$ Forum Theatre is also a practice of making theatre that is itself to a certain degree produced by society.

Narratives in Ashtar's Forum Theatre are constructed by a number of different participants and at a number of different stages. In the process of creating the written script of the play, Ashtar members work with community groups who conduct interviews with the local population. Oral narratives in the form of case studies and personal experiences inform the writing of the scenario. Then, during the Forum Theatre presentation, the narrative text undergoes infinite alterations as audience members step on stage and rewrite the script through their own words and actions. The practice of Forum Theatre is therefore characterized by the embodied dual roles 
of witnessing and performing a situation, and the participants themselves are both product and producer of the narrative put on stage before them. Boal, among others, has emphasized the immediacy of theatre "as a language that is living and present, not as a finished product displaying images from the past." ${ }^{52}$ In this way, Ashtar presents narratives socially constructed by Palestinians in order for their audience to critique and alter various oppressive dynamics in their society - in effect, to write their own history. Therefore the construction of narratives is a political act that can be based on both dominant and suppressed views within society, complicit as well as resistant. ${ }^{53}$ The dominant views are contained in the reiteration of cultural traditions and social norms that are used to reinforce a collective experience and identity. The suppressed and resistant views are able to assert themselves in the rewriting of past and current histories in order to provoke change in the status quo. ${ }^{54}$ History-writing as practiced in the forum is a personal and collective act, in which individuals act within a collective space. Through the mediation of the Joker, performing one's present condition becomes a political act of history-writing, "a practice in and for the present," with direct implications for the future. ${ }^{55}$

Edward Said describes how the performance of one's actual condition "sparks your consciousness of what you are all about, where you are to be found, how maddeningly complicated are the mechanisms that surround you." He elaborates further, saying how this "moment of unguarded reflection is also the moment of deepest vulnerability." ${ }^{56}$ Explicit in Forum Theatre, the moment of reflection is also a moment of action; the vulnerability is also a moment of power. Boal describes this moment as one of crisis in the dramatic action, where danger and opportunity collide. ${ }^{57}$ The performance of one's condition, or, in other terms, representing oneself, therefore places one in a position of both vulnerability and power. One mechanism Forum Theatre offers in order to challenge the vulnerability of the spectator is the potential to write, and in certain cases reinscribe, history. History is understood here not only as the transmission and circulation of knowledge, but the ability to produce change.

Ashtar has been criticized by some Palestinians for being trained and funded by internationals in order to make use of a "foreign" form of theatre, in which many of their performances have been directed by foreign internationals. ${ }^{58}$ A major obstacle facing Palestinian theatre practitioners has been the lack of professional training programs (for actors, directors, technicians, etc.) that are located in the Palestinian territories. The establishment of such programs has been extremely difficult when more immediate concerns of survival take priority. In order for local theatres to survive, some have turned to foreign funding. While foreign donors may, in fact, dictate the bounds of content in the theatre, the critique is less grounded regarding the actual form the theatre takes. Ashtar's use of Forum Theatre, a form that Boal began practicing in Latin America, has been used specifically to counter the many obstacles Palestinians face in making theatre. In spite of these obstacles, Ashtar's 
Forum Theatre productions are written, acted, and produced by Palestinians and represent an attempt to engage local Palestinian audiences actively in order to provoke collective critique and collective action.

\section{Notes}

${ }^{1}$ While I limit my discussion here to the U.S. mainstream media, an analysis can also be considered regarding the mainstream media in other areas of the world.

${ }^{2}$ Popular Memory Group, "Popular Memory: Theory, Politics, Method," in Making Histories: Studies in History Writing and Politics, ed. Richard Johnson, et al. (Minneapolis: U of Minnesota P, 1982) 205-52.

${ }^{3}$ While I focus on the West Bank because this is where Ashtar Theatre is based, one can extend an analysis to the Gaza Strip, as well as to the work of Palestinian citizens of Israel and those in the diaspora.

${ }^{4}$ Stuart Hall, Representation: Cultural Representations and Signifying Practices (California: Sage Publications, 1997) 1.

${ }^{5}$ Ella Shohat and Robert Stam, Unthinking Eurocentrism: Multiculturalism and the Media (New York: Routledge, 1994) 180-1.

${ }^{6}$ Said also describes the book as "an attempt to render Palestinian lives subjectively," noting that it emerged out of being denied that very right of self-representation. He recounts how the book came out of circumstances at the U.N.'s International Conference on the Question of Palestine in 1983, in which Jean Mohr's photographs of Palestine were permitted to be hung in the entrance hall only under the condition that no text be affixed to the photographs. After the Last Sky is thus comprised of Moh'rs photographs accompanied by Said's text. Edward W. Said, After the Last Sky: Palestinian Lives (New York: Columbia U P, 1999) vii, 3, 4; and Edward Said, "The Burdens of Interpretation and the Question of Palestine," Journal of Palestine Studies 16.1 (1986): 36.

${ }^{7}$ The denial of the Palestinian people is captured most succinctly in the oft-cited Zionist slogan, a land without a people for a people without a land. For more scholarship on the silencing of Palestinian history and the Palestinian narrative, see Said's The Question of Palestine, in addition to articulations in After the Last Sky. From another perspective, that of biblical studies, see Keith W. Whitelam's The Invention of Ancient Israel: The Silencing of Palestinian History (New York: Routledge, 1996).

${ }^{8}$ These different audiences may include the international theatre world as well as current and potential funders.

${ }^{9}$ Ella Shohat, Israeli Cinema: East/West and the Politics of Representation (Austin: U of Texas P, 1989) 3.

${ }^{10}$ I choose to speak of performance and writing along these lines in order to emphasize how each shapes and is shaped by the other. Moreover, in the case of Palestine, I want to specifically challenge the limits of who has access to and contributes to the body of text about Palestine, as well as the potential of that text.

"Popular Memory Group, "Popular Memory" 240-41.

${ }^{12}$ Lila Abu-Lughod and Ahmad H. Sa'di, ed. "Introduction: The Claims of Memory," in Nakba: Palestine, 1948, and the Claims of Memory (New York: Columbia U P) 3.

${ }^{13}$ Ghassan Kanafani was a prominent Palestinian writer of literary, critical, and journalistic texts. Born in Acre in 1936, Kanafani was forced to leave Palestine in 1948 and remained in exile his entire life. He was assassinated in Beirut in 1972. The Israeli secret service is said to have claimed responsibility.

${ }^{14}$ Barbara Harlow, After Lives: Legacies of Revolutionary Writing (New York: Verso, 1996) 55, 71.

${ }^{15}$ Popular Memory Group, "Popular Memory" 207.

${ }^{16}$ In the introduction to their edited book on the role of memory to the events of 1948 (referred to as the Nakba, "catastrophe" in Arabic), Lila Abu-Lughod and Ahmad H. Sa'di speak of the Nakba as an ongoing condition. They write that "the Nakba is not over yet," for after sixty years the same conditions of expulsion and destruction that took place in 1948 continue to this day. Abu-Lughod and Sa'di, "Introduction: The Claims of Memory" 10.

${ }^{17}$ As one example, Harlow notes the P.L.O. Research Center in Beirut, "an institution whose premises were ransacked and archives confiscated by the Israeli army when it invaded Lebanon in 1982." Harlow, After Lives 8. 
${ }^{18}$ Rosemary Sayigh, "Women's Nakba Stories," in Nakba 137. In her discussion on the "EuroAmerican mode of history writing," Sayigh is drawing on the work of E. Valentine Daniel. Regarding the writing of national histories, she notes the tendency not only to "exclude the local, the gendered, and the personal," but also that the desire for unification tends to marginalize "internal differences." Sayigh, "Palestinian Camp Women as Tellers of History," Journal of Palestine Studies 27. 2 (1998) 42; and Sayigh, "Women's Nakba Stories" 136.

${ }^{19}$ See Hala Kh. Nassar, "Stories from under Occupation: Performing the Palestinian Experience," Theatre Journal 58 (2006) 25-6. I am quoting from Nassar's English translation. A full English translation can be found in Short Arabic Plays: An Anthology, ed. Salma Khadra Jayyusi (New York: Interlink Books, 2003).

${ }^{20} \mathrm{I}$ am using this phrase as articulated by Nadia Abu El-Haj in her book Facts on the Ground, which she describes as "a study of how archaeology intervened in the world, creating new phenomena that shaped the 'material-semiotic' objects and the political, territorial, and national-cultural realities within which claims to and struggles for the present and the future have come to be framed." Facts on the Ground: Archaeological Practice and Territorial Self-Fashioning in Israeli Society (Chicago: U of Chicago P, 2001) 277.

${ }^{21}$ See her opening stage directions as translated in Short Arabic Plays 82.

${ }^{22}$ Nassar, "Stories from under Occupation" 26.

${ }^{23}$ Hala Nassar, "Palestinian Theatre: Between Origins and Visions.” Diss. Freie Universität, Berlin, 2001. While noting the tradition of women storytellers in Palestinian culture, she specifically refers to the opening and closing formulaic statements made by the traditional figure of the storyteller, as well as a way of interacting with the audience.

${ }^{24}$ Beyond that of narrator, the particular roles and functions ascribed to al-hakawati depend on the historical period, geographical region, and the purpose for which al-hakawati is being utilized. See Friederike Pannewick, "Redemptive Narrating: The Hakawati in Contemporary Arabic Theatre" in Myths, Historical Archetypes and Symbolic Figures in Arabic Literature, ed. Angelika Neuwirth, et al. (Stuttgart: Franz Steiner, 1999); and Reuven Snir's discussion of the theatre and al-hakawati in his book Palestinian Theatre (Wiesbaden: Reichert, 2005) 133-6.

${ }^{25}$ Much scholarly literature has been written on the origins of theatre in the Arab world, with a focus on early theatrical forms such as al-hakawati as a way to counter dominant forms of the theatre based on European models. Along with al-hakawati, other indigenous forms include khayal al-zill, karagöz, sanduk al-'ajab, ta'ziyah, as well as social and cultural rituals that make use of explicit performance elements. See Shmuel Moreh, Live Theatre and Dramatic Literature in the Medieval Arabic World (New York: New York U P, 1992); 'Ali al-Ra'i, Al-Masrah fi 'l-Watan al-Arabi (Kuwait: al-Majlis al-Watani lil Thaqafa wa al-Funun wa al-Adab, 1980); and Pannewick, "Redemptive Narrating."

${ }^{26}$ Pannewick describes how the "communicative strategies" the storyteller employed became "a vigorously discussed model of the so-called authentic Arabic theatre." "Redemptive Narrating" 337 , 341. See also Nassar, "Stories from under Occupation."

${ }^{27}$ See Moreh, Live Theatre and Dramatic Literature in the Medieval Arabic World.

${ }^{28}$ Nassar quotes Fanon, describing how al-hakawati became a political tool under colonization. According to Fanon, the colonizing powers in Algeria were aware of such a tool and systematically arrested these storytellers. See Nassar, "Stories from under Occupation" and Frantz Fanon, The Wretched of the Earth (New York: Grove P, 1968) 240-1.

${ }^{29}$ Snir specifically locates al-Hakawati troupe as most successfully marking the emergence of professional theatre in Palestine. See Snir, Palestinian Theatre.

${ }^{30}$ Edward Muallem, interview with the author, 5 July 2007.

${ }^{31}$ Susan Slyomovics, “'To Put One's Fingers in the Bleeding Wound': Palestinian Theatre under Israeli Censorship," The Drama Review (TDR) 35.2 (1991): 23.

32 "Perspectives on Palestinian Drama and Theatre: A Symposium," in Theatre in Israel, ed. Linda Ben-Zvi (Ann Arbor: U of Michigan P, 1996) 337.

${ }^{33}$ Nassar, "Palestinian Theatre: Between Origins and Visions" 71.

${ }^{34}$ As cited in Nassar, "Stories from under Occupation" 18. Dov Shinar, Palestinian Voices: Communication and Nation Building in the West Bank (Boulder: Lynne Rienner, 1987) 138. plays.

${ }^{35}$ See Shinar, Palestinian Voices, and Snir, Palestinian Theatre, for longer discussions on specific

${ }^{36}$ Although their Forum Theatre work is primarily directed toward working with local Palestinian audiences, their work as a whole, they acknowledge, is meant to be in dialogue with the international theatre world. This may be one reason why their website is mainly available only in English.

${ }^{37}$ The Theatre of the Oppressed Festival titled "Building Bridges, Breaking Barriers" was sponsored by the European Commission, in addition to local support from Palestinian organizations. Over forty 
performances were staged in twenty-two locations throughout the West Bank, including cities and villages. Ashtar performed both its Forum Theatre and Legislative Theatre productions.

${ }^{38}$ Augusto Boal, Theatre of the Oppressed (New York: TCG, 1985). A more expanded articulation of Forum Theatre can be found in his Games for Actors and Non-Actors (New York: Routledge, 2002), which Ashtar has translated into Arabic (translation and introduction by Walid Abu Bakr, 2005).

${ }^{39}$ Iman Aoun, "Different Art Forms, Mutual Concerns," tr. Fatin Farhat and Antoine D. Nesnas, in Community Culture and Globalization (Rockefeller Foundation, 2002) 329.

${ }^{40}$ There are hundreds of Israeli checkpoints in the West Bank alone. Since 1967, when Israel began its military occupation of the West Bank, a policy of movement restrictions for Palestinians was put in place. In 1991 and reinforced in 1993, a more elaborate policy of Israeli military checkpoints and permits was established between the West Bank and Israel, the West Bank and East Jerusalem, and between cities and villages within the West Bank itself. During the Theatre of the Oppressed Festival, for instance, a number of performances were canceled because the Israeli military would not let Ashtar pass through a checkpoint in order to reach their audience. Because of the system of Israeli control in place, no performance was guaranteed until Ashtar actually reached their scheduled destination on the day of the performance.

41 "Popular Theatre in Palestine Project," a Civil Society Promotion Initiative proposed by CARE International in the West Bank and Gaza and Ashtar Theatre, 2000. 13 August 2008. <http://www. careinternational.org.uk/download.php?id $=55>$.

${ }^{42}$ Quoted from Ashtar's website, as well as in the publication commemorating Ashtar's tenth anniversary, Ashtar: A Blazing Stage. 13 August 2008. <http://www.ashtar-theatre.org/forum/shakers99. html>.

${ }^{43}$ Aoun, "Different Art Forms" 327, 325.

${ }^{44}$ See footnote 25 in Nassar, "Stories from under Occupation" 21 . The translation I use is a slightly different version than the one Nassar quotes. Frantz Fanon, The Wretched of the Earth (New York: Grove Weidenfeld, 1968) 240.

${ }^{45}$ Interview with Iman Aoun, 19 June 2007. Naji al-'Ali was expelled from Palestine at the age of ten (like Handala). He became a celebrated cartoonist throughout the Arab world, facing not only censorship but death threats because of his sharp critique of international, regional, and local politics in the Arab world. He was assassinated in London in 1987.

${ }^{46}$ Aoun, "Different Art Forms" 323.

${ }^{47}$ Quoted in "Naji al-'Ali Remembered," MERIP Middle East Report 149 (1987): 27.

${ }^{48}$ Aoun, "Different Art Forms" 329.

${ }^{49}$ As of yet, there are no official or institutional archives of the theatre work of Palestinians, therefore making it difficult to locate, watch recordings, or read accounts of specific performances. Aware of this, Ashtar Theatre has been working toward documenting their work and recording their performances; I was unfortunately unable to obtain any recordings of the Abu Shaker play of 2001. For more on the issue of theatre archives, see Nassar, "Palestinian Theatre: Between Origins and Visions."

50 "Popular Theatre in Palestine Project" 5, 4.

${ }^{51}$ In 2003, an evaluation of Ashtar's Forum Theatre productions and their impact on the audience and civil society at large was conducted by David Silver, an international consultant, contracted by CARE International.

${ }_{52}^{52}$ Boal, Theatre of the Oppressed 126. Emphasis in the original.

${ }^{53}$ Amy Shuman, "Gender and Genre" in Feminist Theory and the Study of Folklore, ed. Susan Hollis, et al. (Chicago: U of Illinois P, 1993) 73.

${ }^{54}$ Explicitly addressing future change, Ashtar's more recent productions have included Legislative Theatre. In 2006, they published in Arabic a study based on local audience recommendations for their Legislative play The Story of Mona, which addresses the issues of arranged marriages, honor killings, and young women's right to education.

${ }_{55}^{55}$ Popular Memory Group, "Popular Memory" 207, 240-1.

${ }^{56}$ Said, After the Last Sky 100.

${ }^{57}$ Boal uses the phrase "Chinese crisis" to describe this moment. He writes: "in Chinese, there is no single ideogram for the word 'crisis,' which is instead expressed by two ideograms, one meaning 'danger' and the other 'opportunities.' The collision of these two meanings defines 'crisis' in its usage in Theatre of the Oppressed terminology." Augusto Boal, The Rainbow of Desire: The Boal Method of Theatre and Therapy (New York: Routledge, 1995) 59.

${ }^{58}$ Based on interviews conducted during field research between June and August of 2007, the issues of foreign funding and resources were at times brought up as points of critique. Ashtar Theatre, of course, is not alone in this matter, considering the lack of a nation-state to support such cultural projects and the dire socio-political circumstances for Palestinians. 
